\title{
Analitik Hiyerarşi Seçim Yöntemi ile Otel Personeli Seçimi Kriterlerinin Değerlendirilmesi: Giresun İli Örneği
}

\section{Dr. Öğretim Üyesi Hakan Akyurt}

Gelis tarihi: 07.08.2019

Kabul tarihi: 22.08.2019

\section{Atıf bilgisi:}

IBAD Sosyal Bilimler Dergisi

Sayı: Özel Sayı Sayfa: $64-78$

Yıl: 2019

This article was checked by Turnitin. Similarity Index 8\%

${ }^{1}$ Giresun Üniversitesi, Türkiye,

hakan.akyurt@giresun.edu.tr

\section{ORCID ID 0000-0002-6522-684X}

* Sorumlu yazar
ÖZ

Turizm sektörünün ekonomik olarak artan önemi nedeni ile günümüz işletmeleri maliyetlerini azaltmak için yoğun çaba harcamaktadır. Otel yönetimlerinin maliyetleri azaltmak ve sürekli çalışan bir personel kadrosunu oluşturması gerekmektedir. $\mathrm{Bu}$ nedenle çalışmada, Giresun ilinde faaliyet göstermekte olan turizm ișletme belgeli otel yöneticilerinin personel seçimlerinde hangi kriterlerin öncelikli olarak dikkate aldıklarının belirlenmesi amaçlanmıştır. Araştırma yönteminde, Giresun ili otel yöneticilerinden alınan veriler doğrultusunda "Analitik Hiyerarşi Seçim” (AHP) yöntemi kullanılmıştır. İlk olarak karşılaştırmalı matrisler oluşturulmuş ardından geometrik ortalamalar hesaplanmış ve Super decision V 3.2 programı ile analiz edilmiştir. Analiz sonuçlarında, "yabancı dil" kriterinin personel seçiminde en önemli kriter olduğu bulgusu elde edilmiştir.. Personel seçiminde diğer önemli kriterlerin ise, "deneyim, fiziksel özellikler, sorumluluk, örgütsel bağlllık, eğitim ve fiziksel özellikler" olduğu belirlenmiştir. Araştırma da elde edilen sonuçlara göre, "eğitim" kriterinin ilk sıralarda olmaması, otel yöneticilerinin turizm eğitimine karşı algılamalarının farklılığını ortaya koymaktadır. Araştırma da ortaya çıkan sonuçlar sektörde çalı̧̧mak isteyen öğrenciler için kendilerini nasıl yetiştirmeleri gerektiği konusunda yararlı bir kaynak olacaktır.

Anahtar Kelimeler: Turizm, Otel İ̧̧letmeleri, Personel Seçimi, AHP yöntemi 


\section{Evaluation of Hotel Personnel Selection Criteria with Analytical Hierarchy Selection Methodology: Example of Giresun Province}

\section{Dr. Hakan Akyurt}

First received: 07.08 .2019

Accepted: 22.08 .2019

\section{Citation:}

IBAD Journal of Social Sciences

Issue: Special Issue Pages: 64-78

Year: 2019

This article was checked by Turnitin. Similarity Index 8\%

1 Giresun Universitiy, Turkey, hakan.akyurt@giresun.edu.tr

ORCID ID 0000-0002-6522-684X

* Corresponding Author

\begin{abstract}
Due to the economically increasing importance of the tourism sector, today's enterprises are working hard to reduce their costs. Hotel management needs to reduce costs and create a permanent staff. Therefore, in this study, it is aimed to determine which criteria are taken into consideration in the selection of personnel of tourism management in Giresun province. In the research methodology, Analytical Hierarchy Selection (AHS) method was used in the direction of data obtained from hotel managers in Giresun province. Firstly, comparative matrices were created, then geometric means were calculated and analyzed with Super decision V 3.2 program. According to the results of the analysis, the "foreign language" criterion is the most important criterion in personnel selection. Other important criteria in the selection of personnel are "experience, physical characteristics, responsibility, organizational commitment, training and physical characteristics". According to the results of the research, the lack of the "education" criterion reveals the differences in the perception of hotel managers towards tourism education. The results of the research will be a useful resource for students who want to work in the sector on how to train themselves.
\end{abstract}

Keywords: Tourism, Hotel Establishments, Personnel Selection, AHP method 


\section{GİRIŞ}

Turizm sektörünün istihdama olan etkisinin artması ile birlikte, turistik işletmelerin personel seçim kriterleri de farklılaşmaya başlamıştır. Özellikle Türkiye'de son yıllarda artan otel sayısı ve turizme olan ihtiyaç nedeniyle sektörün istihdam açığ 1 fazlalaşmıştır. Ülkemizde turizmin sezonluk olması nedeni ile istihdam edilecek kişiler genellikle mart ile aralık ayları arasında işe alınmaktadır. Ancak, ulaşım ve iletişim araçlarının gelişimi ile birlikte şehir otellerinin sayısı artmıştır. Şehir merkezlerindeki otellerin mevsimsellik özelliğinin olmaması ve tüm yıl faaliyette bulunmaları nitelikli personel istihdamını zorunlu kılmaktadır.

Otellerin personel alımlarında diğer sektörlere göre farklılıklar bulunmaktadır. Çalışma koşulları ve turizmin doğal yapısı gereği nitelikli ve de turizm şartlarına uygun personellerde aranan nitelikler değişmektedir. Turizm sektörünün yoğun ve değişken yapısı, rakip otel işletmelerinin sayısının fazlalığı personel devir hızının fazla olmasına neden olmaktadır. Özellikle turizm belgeli ve yıldızlı otel işletmeleri, sürekli istihdam edecekleri personellerinde bazı özellikler aramaktadır. Bunun en büyük nedeni, turistlerle sürekli olarak iletişim halinde olacak personelin niteliklerinin işletmelerine uygun olma arayışıdır. Otel yöneticilerinin personel seçimlerinde kriterlerin net bir şekilde ifade edilmiyor olması ve personel alımlarında adayların hangi kriterlerle karşılaşacağının bilmemesi belirsizlik yaratmaktadır. $\mathrm{Bu}$ nedenle, bir otel işletme yöneticisinin personel alımında hangi kriterlere önem verdiğinin bilinmesi, turizm eğitimi, sektör beklentileri ile akademik bakış ve istihdam edilmeyi bekleyen bireyler açısından önem arz etmektedir.

$\mathrm{Bu}$ çalışma da, otel yöneticilerinin personelleri ile ilgili olarak arzu ettikleri ve beklentileri ortaya konmaktadır. Bir otelin aradığı personel kriterlerinin tespit edilmesi, otel işletmelerinde çalışmayı düşünen öğrencilerin veya halkın kendi özelliklerini geliştirmesine yardımcı olacaktır. Ayrıca bu çalışma ile turizm sektörü beklentileri ile turizm eğitimi veren kuruluşların beklentileri arasındaki farklılıklar ortaya çıkmaktadır. Otel yöneticilerinin personel alımında dikkat ettikleri hususların belirlenmesi, turizm eğitimlerinde hangi konulara ağırlık verilmesi ve geliştirilmesi gerektiğini ortaya koyacaktır. Araştırma da Analitik Hiyerarşi süreci analiz tekniği kullanılarak, literatür çalışması ile elde edilen otel işletmelerinde personel seçim kriterleri arasında önemlerine göre derecelendirme yapılmıştır. Araştırma konunun AHP ile incelenmesi bakımında otel işletme yöneticilerinin düşünceleri ile oluşturulması bakımından turizm alanındaki çalışmalarda farklılık sunmaktadır.

\section{LITERATÜR İNCELEMESİ}

\subsection{Turizm Sektöründe İnsan Kaynakları Yönetimi}

Turizmde insan kaynakları yönetimi kavramının daha iyi anlaşılması için genel anlamda insan kaynakları kavramını ele almak uygun olacaktır. İnsan kaynakları yönetimi, "işletmelerin insan kaynaklarını işletme içi, insanlara ve genel çevresine faydalı olacak şekilde, kanunlar çerçevesinde, işe alım, kontrol gibi faaliyetleri de yapan ve işletmenin tümü için sistematik bir yap1 oluşturan çalışmaların tamamı" olarak tanımlanmaktadır (Sadullah, 2002, s. 11). İnsan kaynakları yönetimi tüm işletmeler için, "nitelikli ve yetenekli personelin işe alınması, bu niteliklerin ve yeteneklerin en verimli şekilde işletme amaçları doğrultusunda kullanılması ve personelin sürekliliğinin sağlanması" olarak ifade edilmektedir (Saruhan ve Yıldız, 2012, s. 21).

Sektörler incelendiğinde birbirinden farklı birçok işletme türü ile karşılaşmak mümkündür. Turizm işletmeleri ise genel olarak restoranlar, seyahat acenteleri ve otel çeşitleri ile ifade edilen işletme türlerinden oluşmaktadır. Özellikle otel işletmelerinin çeşitliliği ve sundukları hizmetler bakımından farklı olması nedeni ile birçok farklı türde personel istihdam edilme zorunluluğu ortaya çıkmaktadır. Turizmin ülkemizde mevsimsellik özelliğe sahip birçok otel işletmesinden oluşması, turizmde işe alınan personelin devir hızının yüksek olması sonucunu ortaya çıkarmaktadır. Özellikle güney ve batı sahil bölgelerinde yılın bazı aylarında kapanan ve personelini bırakan otel işletmeleri tekrar personel alımlarında ve işgören devir hızında önemli bir oran teşkil etmektedir. Bu bakımdan özellikle otel işletmelerinde insan kaynakları yönetiminin önemi büyüktür. Otel işletmelerinde insan 
kaynakları yönetimi diğer sektörlere göre hem personelin işlerinin farklılığı hem de turizmin mevsimsellik özelliği nedeni ile daha zor bir süreç olarak kabul edilmektedir.

Özellikle günümüz teknolojisi ve iletişim imkanları sonucu insan kaynakları birimlerinin görevlerinde bürokratik işlemlerde azalmalar olmuştur. İnternet yolu ile iş başvurularının alınması, kariyer planlama siteleri ve işletmelerin kendi web siteleri ile personel seçiminde bürokratik işlemler azalmıştır. $\mathrm{Bu}$ durum hem işletmeler hem de iş başvurusu yapan insanlar için işlerin kolaylaşmasını sağlamıştır. İnsan kaynaklarının işletmeler açısından temel işlevleri genel anlamda aynı özellikleri içinde barındırmaktadır. İşletmeler açısından genel olarak insan kaynakları yönetiminin işlevlerini aşağıdaki tablo-1 ile açıklamak mümkündür (Benligiray, 2013, s. 13):

Tablo 1. İnsan Kaynakları Yönetiminin İşlevleri

\begin{tabular}{|c|c|}
\hline Genel Faaliyetler & İşlevler \\
\hline $\begin{array}{l}\text { İşletme içi ve dişı işler ve insanlar için } \\
\text { planlama yapmak }\end{array}$ & $\begin{array}{c}\text { İnsan kaynakları planlamak } \\
\text { İş analizi yapmak } \\
\text { İş tasarımı oluşturmak }\end{array}$ \\
\hline İnsan Kaynaklarını Sağlamak & $\begin{array}{c}\text { Personel bulmak } \\
\text { İşe yerleştirmek } \\
\text { İşe alıştırmak } \\
\text { Sosyalleştirmek }\end{array}$ \\
\hline İnsan kaynaklarını elde tutmak & $\begin{array}{c}\text { Ücretlendirme } \\
\text { İşletmeye bağlılığı arttırmak } \\
\text { İş sağlı̆̆ını ve güvenliğini sağlamak } \\
\text { İş ilişkilerini sürdürmek } \\
\text { Sosyal etkinlikler yapmak }\end{array}$ \\
\hline $\begin{array}{l}\text { Personelin ve işletmenin performansını } \\
\text { arttırmak }\end{array}$ & $\begin{array}{c}\text { Performans değerlendirmek } \\
\text { Ödüllendirmek } \\
\text { Kariyer planlamak } \\
\text { Disiplin } \\
\text { İnsan kaynakları yönetimi sonuçlarını } \\
\text { değerlendirmek } \\
\end{array}$ \\
\hline
\end{tabular}

Kaynak: Benligiray, S. (2013). İnsan Kaynakları Yönetimi ve Örgütlenmesi. İçinde, İnsan Kaynakları Yönetimi, s. 13.

Turizm işletmeleri, ürün ve hizmeti bir arada sunan ve birçok sektör ile işbirliği içinde çalışmak zorunda olan çok yönlü bir sektördür. Turizmin genel yapısı nedeni ile otel işletmelerinde çalışacak personelin diğer iş alanlarına göre çok daha farklı bir yapıda çalışmaktadır. Turistlerin istek ve ihtiyaçlarının çok farklı olması, sürekli değişim göstermesi ve beklentilerinin karşılanmaması durumunda turistik talebi doğrudan etkilemesi nedeni ile otel işletmelerinde istihdam edilecek personelin niteliği önem arz etmektedir. Bir otelde çalışan personelin niteliğinin ve turiste karşı hizmet sunumunun olumsuz bir şekilde oluşması, sadece o personeli değil tüm işletmeyi olumsuz olarak etkilemektedir. Bu nedenle turizm sektörünün önemli bir kısmını oluşturan otel işletmelerinin personel seçimini çok hassas ve özenli olarak gerçekleştirmesi gerekmektedir. Turizmde insan kaynakları yönetimi işletmenin sürdürülebilirliği, kar elde etmesi ve maliyetleri bakımından en önemli konuların başında gelmektedir. 
Turizm alanında insan kaynakları uygulamaları ise seyahat acenteleri, tur operatörleri, belediye ve turizm işletme belgeli otel çeşitleri, turizm belgeli restoran ve eğlence yerleri gibi birçok farklı işletmeyi ele almaktadır. Bununla birlikte, turizmde faaliyet göstermekte olan işletmelerin farklı özelliklere sahip birçok personele ihtiyacı olduğundan, insan kaynakları faaliyetlerinin sistematik ve planlı bir şekilde yürütülmesi önem arz etmektedir. Turizm işletmelerinde insan kaynakları departmanın personeli seçme, ücretleri belirleme, eğitim verme, personeli geliştirme, kurum içinde terfi sistemi, kariyer planlama ve tüm personelin koordineli çalışmasına yardımcı olma gibi birçok farklı işlevi yaptığı bilinmektedir. Diğer sektörlere oranlar turizmde personelin yönetim işlevi daha karmaşık bir yapıya sahiptir (Purcell, 2003, s. 512). Bu nedenle, turizm işletmelerinde personel seçimi diğer işletmelere göre farkl1lıklar göstermektedir. Özellikle turizm sektörünün en önemli işletmeleri olan otel işletmeleri karmaşı personel yapısı ile daha da özenli bir şekilde personel seçimi yapmaktadır. Çok farklı niteliklere sahip farklı mesleklerden birçok personelin istihdam edilmesi, eğitilmesi ve sürekli olarak çalıştırılması zor bir süreç olduğundan, personel seçimi konusu hem oteller hem de istihdam edilecek insanlar açısından önem arz eden bir konudur.

\subsection{Otel İşletmelerinde Personel Seçimi}

Turizm sektöründe insan kaynakları konusunda ağırlıklı olarak otel işletmelerinin varlığı söz konusudur. Sanayi işletmelerine göre modern yönetim sistemlerine geçişte sorunlar yaşanmıştır. Diğer sektörlerde teknolojinin gelişimi ile birlikte yeni yönetim biçimlerine hılı bir geçiş söz konusu iken, ülkemizde hala tam anlamıyla otel işletmelerinin bir kısmı yeni yönetim sistemlerine geçişi sağlayamamıştır. Zincir ve büyük işletmeler dışında konaklama işletmelerinin insan kaynakları bölümünün tam olarak oluşmadığ görülmektedir. Bu durum hem işletme yöneticileri hem de personel açısından olumsuz sonuçlara yol açabilmektedir. Çağın getirdiği yönetim biçimlerine uyum sağlama konusunda turizmin yapısından gelen ve henüz tam anlamıla modern yönetim biçimlerini benimsemeyen konaklama işletmelerinin mevcut olduğu görülmektedir. Günümüz insan kaynakları yönetim sistemi sadece personel alımı ile değil, işletmenin tüm personelinin işe devamı sırasında da işlevini sürdürmektedir (Genç, 2009, s. 361).

Otel işletmelerinde personel seçimi, işletme çalışanlarının emek yoğun bir sistem içinde çalışmalarından dolayı zor bir süreçtir. Şehir otelleri dışında birçok otel işletmesinin mevsimsellik özelliği, personeli seçme ve elinde tutma konusunda zorluklar yaşamasına neden olmaktadır. $\mathrm{Bu}$ nedenden dolayı, otel yöneticilerinin personel seçimleri ve insan kaynakları departmanları ne kadar sistematik olsa bile, personel seçiminde ve işletmeye bağll1ık konusunda sorunlar görülebilmektedir. Çalışma saatlerinin ve günlerinin farklılığı, fiziksel zorluklar, sürekli insan ilişkileri ile otel işletmelerinin yıpratıcı bir çalışma şekli vardır. Bu durum otel işletmelerinin personel devir hızlarının diğer sektörlere göre daha fazla olması sonucunu ortaya çıkarmaktadır (Tüzün, 2013, s. 63). Ancak, ülke ekonomilerine ekonomik katkısı ve niteliklere bakılmadan her insana uygun iş yapısı, otel işletmelerini diğer sektörlere göre istihdam oranlarında olumlu yönde farklılaştıran belirgin özelliklerdir. Otel işletmeleri, insan kaynakları ihtiyacının belirlenmesinde özellikle turist sayısı ile doğru orantılı olarak planlama yapmaktadır. Otelin yoğun olduğu dönemler ile az talep aldığ dönemler arasındaki personel sayısı aynı olmamaktadır. Bu yönü ile otel işletmeleri birçok sektördeki işletmelerden ayrılmaktadır. Turist sayısına göre personel durumu da personel seçimlerinin belirlenmesinde y1l içinde farklılıklar oluşacağını göstermektedir. Otel işletmeleri, personellerini seçerken ve insan kaynakları ihtiyaçlarını planlarken oda ve yatak başına düşen personel sayısına göre hareket etmektedir. Burada amaç, otelin maliyetlerini azaltmak ve sürdürülebilir bir personel seçimi gerçekleştirmektir (Erdem, 2004, s. 46).

Otel işletmelerinde işe alınacak personelin belirlenmesinde işletmeler arasında farklılıklar olmaktadır. Her otel işletmesi kendi personel seçim sürecini ve kriterlerini kendisi belirlemektedir. $\mathrm{Bu}$ nedenle otel işletmeleri için belirlenmiş bir standart yoktur. Otel işletmelerinin yapısının uluslararası veya ulusal bir boyutta olması, yatak kapasitesi ve işletmenin büyüklüğü, kurulu olduğu yerin ve bina durumları, vermiş olduğu ürün ve hizmet sunumu personel seçiminde farklılık olmasının bazı nedenlerindir. Otel işletme yöneticileri istihdam için personel alımlarında yukarıda belirtilen özellikler gibi birçok farklı unsuru da dikkate almak zorundadır. Genel olarak otel işletmelerinde istihdam edilen personelin yüzde biçiminde dağılımı tablo 2'de gösterilmektedir (Olalı ve Korzay, 1993, s. 615).

IBAD Sosyal Bilimler Dergisi, (Özel Say1), 2019 
Tablo 2. Otellerde İnsan gücü Dağglımı

\begin{tabular}{c|c}
\hline Departmanlar & Yüzdesi (\%) \\
\hline İdari personel & 3.7 \\
Ön büro personeli & 19.3 \\
Bar ve animasyon personeli & 10,3 \\
Kat hizmetleri personeli & 26.8 \\
Servis personeli & 34.1 \\
Mutfak bakım ve onarım personeli & 5.8 \\
& \\
\hline
\end{tabular}

Kaynak: Olalı ve Korzay, Otel İşletmeciliği, s.615.

Yukarıda belirtilen oranlar her otel işletmesi için farklılıklar gösterebilir. Otelin büyüklügü, konumu, mevsimsellik özelliği, turistik talebi, yatak kapasitesi ve birçok unsur daha otellerde istihdam edilecek personelin departman yüzesinde farkl1lıklar oluşturabilir. Ancak, her ne kadar bu oranlar farklı olsa otel işletmelerinin sunmuş olduğu hizmetler ve ürünlerden dolayı personellerin niteliklerindeki farklılıklar her otel için aynı olacaktır. Otel içinde turistleri ilk karşılayan Belboy, resepsiyon memurları, temizlik işleri yapan meydancılar, aşçılar, servis elemanları, housekeeping personeli, animatörler, doktor, hemşire, yüzme eğitimcileri, kayak hocaları gibi birçok farklı meslek dalından personel istihdam edilmesi gerekebilmektedir. $\mathrm{Bu}$ durum da personel seçiminde otel yöneticilerinin ne kadar zor bir süreç yaşadığını göstermektedir.

Otel işletmelerinin yapısı nedeniyle personel seçiminde zorlu bir süreç yaşanmaktadır. Konu ile ilgili olarak yapılan araştırmalarda genel olarak otellerde personel seçiminde ortak niteliklerin arandığı görülmekle birlikte, nitelik gerektirmeyen işlerin de varlığından dolayı nitelik aramadan da istihdam yapıldığı bilinmektedir. Otel işletmelerinde birçok araştırmacı tarafından yapılmış olan çalışmalarda genel olarak personel seçiminde istenen kriterleri aşağıdaki gibi özetlemek mümkündür (Jiang ve Susskind, 1997; Sonnentag ve Frese, 2002; Demir, 2004; Erdem, 2004; Serçeoğlu, 2013; Çetinsöz ve Akdağ, 2015):

- Sorumluluk sahibi olma,

- Örgütsel bağlılık,

- Yabanc1 dil bilgisi,

- Sakin mizaç,

- Dürüstlük,

- Disiplin,

- İş ile ilgili eğitim,

- Tecrübe sahibi olmak (deneyim),

- Fiziksel görünüm (bakım ve temizlik),

- Çalışma arkadaşları ile uyum (takım çalışması),

- Çabuk öğrenme.

Yukarıda belirtilmiş olan otel işletmeleri personel alımındaki kriterler, ülkeye, bölgeye, işletmelere ve hatta otel yöneticilerinin yönetim anlayışlarına göre farklılık gösterebilir. Örneğin, Trabzon Uzungöl turistik destinasyonunda yabancı dil bilgisi için Arapça dilini bilmek bir personel için daha avantajlıyken, Antalya'da oteller Rusça dilini bilen personel tercih edebilir. Bununla birlikte, otelin konumu ve büyüklüğü gibi birçok kriter daha personel seçimi kriterlerini farklılaştırabilir. Ayrıca, bir personelin nasıl verim vereceğini bilmek çok mümkün olmayacağından, sistematik bir 
personel seçim sürecinden geçmiş olsa bile insan faktörü daima risk oluşturmaktadır. Otel işlemelerinde personel seçimi işletmenin kar durumunu ve sürekliğini doğrudan etkileyen bir süreçtir. $\mathrm{Bu}$ nedenle, personel seçiminde otel yöneticilerinin düşünceleri otelin istihdam durumunda en etkili unsurdur. Otellerin kendi kriterleri ve sistemleri olsa dahi otel yöneticilerinin en son nihai kararı verdiği düşünüldüğünde, otel yöneticilerinin personel seçiminde dikkat ettikleri kriterlerin belirlenmesi ve ortaya çıkarılması önemlidir. Oteldeki işleyişin bozulmaması ve turistlere karşı memnuniyetsizliğin olmaması için otel personelin seçimi üzerinde önemle durulması gereken bir konudur. Otel yöneticilerinin beklentilerinin belirlenmesi ile hem otel işletmelerinde çalışmayı arzu eden insanların kendilerini yetiştirmeleri konusunda hem de turizm sektöründeki otel yöneticilerinin genel olarak personel seçimi vizyonu ile ilgili bilgiler edinilmesinde yararlı olacaktır.

\section{3. İlgili Araştırmalar}

Literatürde çalışma ile benzer nitelikte çalışmalar bulunmakla birlikte, aynı konuda çalışma bulunmamaktadır. Bu durum çalışmanın özgünlüğü için önem arz etmektedir. Benzer çalışmalarda, Göral (2015), otel seçiminde çok kriterli karar verme yöntemlerini kullanmıştır. Çalışmasında internet müşterileri ile fiyat ve fayda arasındaki ilişkilerle Konya ilinde en uygun otel bulmayı amaçlamıştır. Farklı bir çalışma da, Sarıçalı ve Kundakcı (2016), Ahp ve Copras yöntemleri ile otel alternatiflerinin değerlendirmesi üzerine araştırma yapmıştır. Otel seçiminde kullanılacak kriterleri ele alarak, otel seçimi ile ilgili değerlendirmeler ortaya koymuşlardır. Ülen ve Gülmez (2016), tarafından yapılmış olan çalışma da konaklama işletmelerinin tercihlerine ilişkin araştırma yapılmıştır. Bu çalışma da turistlerin konaklama işletme tercihinde ahp yöntemi bir araç olarak ele alınmıştır. Gümüş, Karabayır, Güler ve Arslan, (2017), ahp yöntemi ile Alanya'da tedarikçi seçimine yönelik olarak araştırma yapmışlardır. Çalışmaları, otel işletmelerinin tedarikçi seçiminde kullanılan kriterler üzerinden uygulanmıştır. İpekçi Çetin ve Tarcan İçigen (2018), ahp yöntemi kullanarak konaklama işletmelerine başvuru yapan adayların seçimlerini araştırmıştır. Bu çalışmanın farklılığı, önbüro müdür seçiminde ahp yönteminin kullanılmasıdır. Bir başka çalışma da, İpekçi Çetin, Güven ve Ünal (2019) tarafından otellerin tedarikçi seçiminde Ahp yöntemi kullanılmıştır. Çalışmalarında otellerin en ideal tedarikçileri seçimindeki kriterlere yer verilmiştir. Otel işletmelerine yönelik olarak ahp yöntemi ile farklı çalışmalar bulunsa da, bu çalışmalar genel olarak otel seçimi ve tedarik ziniciri seçimi uygulamaları olarak karşımıza çıkmaktadır. Bunun dışında Ahp yöntemi genel olarak işletme biliminde sık kullanılan bir yöntem olarak belirlenmiştir. Ahp yöntemi turizm alanında son yıllarda daha çok kullanılan ve yeni gelişmeye başlayan bir yöntemdir.

\section{ARAŞTIRMANIN YÖNTEMI}

\subsection{Araştırmanın Amacı}

Araştırmanın temel amacı otel işletmelerine alınan personellerin hangi kriterlere öncelik verilerek alındığının belirlenmesi ve turizm sektöründe otellerde çalışmayı hedefleyen öğrencilerin ve de diğer insanların bu kriterler hakkında bilgi sahibi olmasıdır. Giresun ili otelleri üzerine yapılmış olan çalışma, sektörün genel aynası niteliği taşıyacaktır. Bunun temel sebebi, araştırma da fikirleri alınan otel yöneticilerinin tecrübelerinin fazla olması ve Türkiye'de birçok bölgede çalışmış olmalarıdır. Otel yöneticilerinin personel seçimi yaparken hangi kriterlere dikkat ettiği ve turizmde çalışacak olan insanlardan beklentileri ortaya konulmuş olacaktır. Turizm eğitimi vermekte olan yöneticilere de eğitim müfredatlarını sektör beklentileri konusunda 1şık tutması amaçlanmaktadır.

\subsection{Araştırmanın Evreni ve Örneklemi}

Araştırma Giresun ili genelinde üç ve dört yıldızlı otel yöneticilerine anket tekniği uygulanarak yapılmıştır. Giresun Kültür ve Turizm İl Müdürlüğünün verilerine göre il genelinde turizm belgeli otel sayısı 30'dur. Bu otellerin 17'si üç ve dört yıldızlı oteller, 13'ü ise iki yıldızlı, pansiyon ve apart otellerden oluşmaktadır. Giresun il merkezinde ve merkeze yakın ilçelerdeki apart, pansiyon ve yıldızlı turizm işletme belgeli otel sayısı ise 17 olarak belirtilmektedir (Giresun İl Kültür ve Turizm Müdürlüğü, 2019). Araştırma da, Giresun il merkezi ve yakın ilçelerdeki tüm otel yöneticileri (17 yönetici) ile anket yapılmıştır. Sektörü temsil etme yeteneği bakımından araştırma örnekleminin evreni temsil ettiği düşünülmektedir. 


\title{
3.3. Veri Toplama Yöntemi
}

Araştırma öncelikle anketlerin hazırlanması ve Giresun ili otel yöneticilerine ulaştırılması ile başlatılmıştır. Araştırma da kullanılan anket formu daha önce otel işlemeleri ilgili olarak çalışma yapan araştırmalarının uygulamış olduğu anketlerdeki personel seçim kriterleri alınarak düzenlenmiştir. Araştırma da otel yöneticilerinin personel seçiminde etkili olan 7 kriter belirlenmiştir. $\mathrm{Bu}$ kriterler kendi arasında ikili karşılaştırmalar yapılarak Analitik Hiyerarşi Süreci ile analiz edilmiştir. Kriterlerin birbiri arasındaki önem dereceleri belirlenmiştir. Anketler il merkezindeki otel yöneticileri ile yüz yüze yapılmıştır. Üç ve dört yıldızlı otel yöneticilerinin tamamına anket uygulanmış ve cevapları kaydedilmiştir. $\mathrm{Bu}$ çalışma da uygulanan araştırma kriterleri, otel işletmelerinde personel seçimi konusunda daha önce araştırma yapmış olan araştırmacıların çalışmalarından hazırlanmıştır. Daha önce geçerliliği ve güvenirliliği test edilmiş olan otel işletmelerinde kullanılmış olan personel seçimi kriterlerine göre otel yöneticilerine AHP yöntemine uygun olarak dizayn edilmiştir.

Bu kriterler aşağıda Tablo-3'de belirtilmiştir (Jiang ve Susskind, 1997; Sonnentag ve Frese, 2002; Çetinsöz ve Akdağ, 2015 ).

Tablo 3. AHP Ölçeği Temel Kriterler Tablosu

\section{Temel Kriterler}

\author{
Yabancı Dil (K1) \\ Fiziksel Özellikler (K2) \\ Deneyim (K3) \\ Takım Çalışması (K4) \\ Sorumluluk (K5) \\ Örgütsel Bağlllık (K6) \\ Eğitim (K7)
}

\subsection{Verilerin Analizi}

Araştırma da Analitik Hiyerarşi Süreci (AHP) yöntemi uygulanmıştır. Bu yöntem, Thomas L. Saaty adlı araştırmacı tarafindan ilk olarak 1977 yılında ortaya konulmuştur. Yöntemde amaç, matematiksel teorilerle araştırma konularının arasında hiyerarşik bir sıralama yapma imkanı sunmasıdır (Saaty ve Niemira, 2006, s. 1). Belirlenmiş olan kriterlerin hiyerarşik yapısını ortaya koymaktadır. Bu yöntemin uygulanması aşamasında, öncelikleri sentezlenme, ayrıştırma ve yargıları karşılaştırılma ilkeleri temel yapıyı oluşturmaktadır (Başkaya ve Akar, 2005, s. 275; Korucuk, 2018, s. 347-350).

AHP yöntemindeki uygulama adımları aşağıda sırasıyla belirtilmektedir.

1.Adım: Hiyerarşik Yapıyı Oluşturulma:

Bu adım içinde alternatifler, amaçlar ve kriterler ortaya konmaktadır (Saaty, 2008, s. 85).

\section{Adım: Öncelikleri Belirlenme:}

Araştırma kriterleri arasında karşılaştırma matrisi yapılmaktadır. 1 ile 9 ölçekli olarak önceleklendirme ölçeği kullanılmaktadır (Saaty, 1994, s. 21). Bu durum Tablo-4'de gösterilmektedir.

Tablo 4. AHP Ölçeği Önem Dereceleri Tablosu

\begin{tabular}{clc}
\hline $\begin{array}{c}\text { Önem } \\
\text { Derecesi }\end{array}$ & Tanım & Açıklama \\
\hline 1 & $\begin{array}{l}\text { Eşit derecede } \\
\text { önemli }\end{array}$ & Aynı öneme sahip iki faktör \\
\hline
\end{tabular}




\begin{tabular}{cll}
\hline 3 & Orta derece önemli & $\begin{array}{l}\text { Biri diğerinden az önemli iki } \\
\text { faktör }\end{array}$ \\
\hline 5 & $\begin{array}{l}\text { Kuvvetli derecede } \\
\text { önemli }\end{array}$ & $\begin{array}{l}\text { Biri diğerinden çok önemli iki } \\
\text { faktör }\end{array}$ \\
\hline 7 & $\begin{array}{l}\text { Çok kuvvetli } \\
\text { derecede önemli }\end{array}$ & $\begin{array}{l}\text { Çok yüksek derece önemli bir } \\
\text { faktör, diğeri az etkili }\end{array}$ \\
\hline 9 & $\begin{array}{l}\text { Mutlak derecede } \\
\text { önemli }\end{array}$ & $\begin{array}{l}\text { Faktörlerden biri diğerine göre } \\
\text { çok yüksek derecede } \\
\text { önemlidir. }\end{array}$ \\
\hline $2,4,4,8$ & Ara değerler & $\begin{array}{l}\text { Yukarıda belirlenen değerlere } \\
\text { göre ara değerler. }\end{array}$ \\
\hline
\end{tabular}

\section{Adım: Özvektörü Belirlenme:}

Ortaya konan kriterlerin yüzde önem dağılımlarını belirlemek için, karşılaştırma matrisini oluşturmuş olan sütun vektörlerinden yararlanılmaktadır. "n" sayıda ve "n" bileşenli B sütun vektörü oluşturulmaktadır. B sütun vektörlerinin hesaplanmasında aşağıdaki denklem-1'den faydalanılmaktadır.

$$
\text { (1) } b_{i j}=\frac{a_{i j}}{\sum_{i=1}^{n} a_{i j}}
$$

n sayıda B sütun vektörü, matris formatında bir araya getirilip aşağıda belirtilmiş olan C matrisi elde edilmektedir.

$$
C=\left[\begin{array}{cccc}
c_{11} & c_{12} & \ldots & c_{1 n} \\
c_{21} & c_{22} & \ldots & c_{2 n} \\
\cdot & & & \cdot \\
\cdot & & & \cdot \\
\cdot & & & \cdot \\
c_{n 1} & c_{n 2} & \ldots & c_{n n}
\end{array}\right]
$$

C matrisinden yararlanmak suretiyle, kriterler arasındaki birbirleri ile olan önem değerlerini ortaya koyan yüzde önem dağılımları elde edilmektedir. Bu sonucun elde edilebilmesi için Denklem2'de gösterildiği gibi C matrisini oluşturan satır bileşenlerinin aritmetik ortalaması alınmaktadır. Öncelik Vektörü olarak ifade edilen W sütun vektörü elde edilmektedir.

$$
\text { (2) } w_{i}=\frac{\sum_{j=1}^{n} c_{i j}}{n}
$$

\section{Adım: Tutarlılık Oranı Hesaplanması:}

AHP yöntemi, elde edilen Tutarlılık Oranı (CR) ile, bulunmuş olan öncelik vektörünün ve kriterler arasındaki birebir karşılaştırmaların tutarlılığının test edilebilmesini sağlamaktadır. Sadece AHP yönteminin kullanıldığı bir araştırmada hem kriterlerin hem de alternatiflerin $7 \pm 2$ kuralına uygun olmak zorundadır. $\mathrm{Bu}$ şekilde yapılmadığı takdirde tutarsızlıklara yol açacak ve oluşturulan AHP modelinin en son elde edilen tutarsızlık oranları " 0,10 'den" büyük sonuçlar verecektir. CR hesaplamasının temelini kriter sayısı ile Temel Değer adı verilen $(\lambda)$ bir katsayının karşılaştırılmasıdır. $\lambda$ 'nın hesaplanması için öncelikle A karşılaştırma matrisi ile $W$ öncelik vektörünün matris çarpımından D sütun vektörünü elde edilmesi gerekmektedir. 


$$
D=\left[\begin{array}{cccc}
a_{11} & a_{12} & \ldots & a_{1 n} \\
a_{21} & a_{22} & \ldots & a_{2 n} \\
\cdot & & & \cdot \\
\cdot & & & \cdot \\
\cdot & & & \cdot \\
a_{n 1} & a_{n 2} & \ldots & a_{n n}
\end{array}\right] x\left[\begin{array}{c}
w_{1} \\
w_{2} \\
\cdot \\
\cdot \\
\cdot \\
w_{n}
\end{array}\right]
$$

Denklem-3'de belirtilen, elde edilen D sütun vektörü ile W sütun vektörünün karşılıklı elemanlarının bölümünden her bir değerlendirme kriterine ilişkin temel değer (E) elde edilmektedir. $\mathrm{Bu}$ değerlerin aritmetik ortalaması (Denklem-4) ise karşılaştırmaya ilişkin temel değeri $(\lambda)$ vermektedir.

$$
\begin{aligned}
& \text { (3) } E_{i}=\frac{d_{i}}{w_{i}} i=1,2, \ldots, n \\
& \text { (4) } \lambda=\frac{\sum_{i=1}^{n} E_{i}}{n}
\end{aligned}
$$

" $\lambda$ ” değerinin hesaplanmasının ardından Tutarlılık Göstergesi (CI), Denklem-5 ile hesaplanır.

$$
\text { (5) } C I=\frac{\lambda-n}{n-1}
$$

En son aşamaya gelindiğinde ise CI, Random Gösterge (RI) olarak ifade edilen standart düzeltme değerine bölünür, (Denklem-6) CR değeri elde edilir.

$$
\text { (6) } C R=\frac{C I}{R I}
$$

Hesaplama sonucunda elde edilen CR değerinin 0,10 'den küçük çıkması gerekmektedir. Bu durum, ankete cevap verenlerin cevaplarının tutarlı olduğu anlamını taşımaktadır. CR değerinin 0,10'den büyük çıkması ya AHP yöntemindeki bir hesaplama hatasını ya da ankete katılanların tutarsız cevaplar verdiklerini göstermektedir.

AHP yöntemi yardımı ile daha önce belirtilmiş olan kriterlerin ikili karşılaştırma matrisi oluşturulmuştur. Ardından geometrik ortalamaları alınarak, daha sonra "Super decision V 3.2." programı ile analiz edilerek aşağıdaki bulgulara ulaşılmıştır.

\subsection{Araştırmanın Bulguları}

\begin{tabular}{|c|c|c|c|c|c|c|c|}
\hline Kriterler & K1 & $\mathrm{K} 2$ & K3 & K4 & K5 & K6 & K7 \\
\hline K1 & 1 & 1 & 8 & 1 & 7 & 1 & 1 \\
\hline \multirow[t]{2}{*}{ K2 } & 1 & & & & & & \\
\hline & & 1 & 6 & 2 & 2 & 1 & 1 \\
\hline
\end{tabular}

Temel kriterlerin belirlenmesi ve kriterler biçiminde ifade edilmesinin ardından analizlere geçilmiştir. Öncelikle matrisler yardımıyla kriterlerin geometrik ağırlıkları hesaplanmıştır. Matris sonuçları aşağıda Tablo-5'te verilmiştir.

Tablo 5. Karşılaştırmalı Matris Sonuçları 


\begin{tabular}{|c|c|c|c|c|c|c|c|}
\hline $\mathbf{K 3}$ & $1 / 8$ & $1 / 6$ & 1 & $1 / 4$ & $1 / 2$ & $1 / 4$ & $1 / 6$ \\
\hline $\mathbf{K 4}$ & 1 & $1 / 2$ & 4 & 1 & $1 / 2$ & $1 / 2$ & 2 \\
\hline $\mathbf{K 5}$ & $1 / 7$ & $1 / 2$ & 2 & 2 & 1 & 1 & 1 \\
\hline $\mathbf{K 6}$ & 1 & 1 & 4 & 2 & 1 & 1 & 1 \\
\hline $\mathbf{K} 7$ & 1 & 1 & 6 & $1 / 2$ & 1 & 1 & 1 \\
\hline
\end{tabular}

Matris, ilk matrisin oluşturulması ve geometrik ortalamalarının ardından "Super Decision V 3.2." programı ile analiz edilerek yukarıda gösterilen son matris elde edilmiştir. Geometrik ortalamalar analiz edilerek Tablo-6' da sunulan kriter ağıllık değerleri bulunmuştur. Analiz sonuçlarında, ikili karşılaştırma matrisi tutarlılık değeri sonucu olan CR değeri "0,09162" olarak tespit edilmiştir. CR değerinin 0,10 'dan küçük çıkması, matris karşılaştırmalarda ortaya çıkan sonucun tutarlı olduğunu göstermektedir.

Tablo 6. Temel Kriterlerin Ağırlık Değerleri

\begin{tabular}{c|c|c|c|c|c|c}
\hline $\mathbf{K}_{\mathbf{1}}$ & $\mathbf{K}_{\mathbf{2}}$ & $\mathbf{K}_{\mathbf{3}}$ & $\mathbf{K}_{\mathbf{4}}$ & $\mathbf{K}_{\mathbf{5}}$ & $\mathbf{K}_{\mathbf{6}}$ & $\mathbf{K}_{\mathbf{7}}$ \\
\hline 0,245 & 0,181 & 0,032 & 0,131 & 0,112 & 0,159 & 0,140 \\
\hline
\end{tabular}

Inconsistency: 0,09162

Analiz sonuçlarına göre kriterler arasında en önemli değeri "K1" değeri almıştır. "Yabancı dil" olarak anlamlandırılmış olan bu değer, otel yöneticilerinin en önem verdikleri ve personel seçim aşamalarında ilk istedikleri unsur olarak belirlenmiştir. Bu sonucun ardından ikinci sırada personel seçim unsurunun " 0,181 ” ile "deneyim" unsuru olduğu görüşü ortaya çıkmıştır. Üçüncü olarak " 0.159 " ile "örgütsel bağl1l1k" unsuru, dördüncü sırada " 0,140 " ile "eğitim" unsuru, beşinci olarak " 0,131 " ile takım çalışması unsuru, altıncı olarak " 0,112 " ile "sorumluluk" unsuru ve son olarak "0,032" ile "fiziksel özellikler" unsuru sonuçları ortaya çıkmıştır.

Araştırma bulgularına göre, otel yöneticilerinin işe almayı düşündükleri personellerde ilk olarak yabancı dil durumlarını dikkate aldıkları ortaya çıkmıştır. İş tecrübesi yani deneyim unsurunun ikincil olarak personel seçiminde etkili kriter olduğu görülmektedir. Tecrübeli olan personellerin daha çok tercih edildiği manasına gelmektedir. Diğer bir önemli unsur olan işletmeye ya da örgütsel bağlılık personel seçiminde etkili bir unsur olduğu görülmektedir. Dördüncü sırada gelen personeli eğitim durumu unsuru ise üzerinde düşünülmesi ve tartışılması gereken bir sonuç olarak ortaya çıkmıştır. İş yerindeki takım çalışmasına yatkınlık, sorumluluk sahibi olma ve fiziksel özellikler gibi unsurlar ise daha az öneme sahip unsurlar olarak sıralanmaktadır.

\section{SONUÇ VE ÖNERILLER}

Turizm sektörünün istihdama olan katkısı son yıllarda daha da belirginleşen önemi ile dikkat çekmektedir. Nitelik veya niteliksiz olsa da birçok kişi için istihdam kaynağ 1 olan bir sektör haline gelmiştir. Bu nedenle özellikle istihdam edilecek personelin niteliği önem arz etmektedir. Araştırma da, Giresun ili üç ve dört yıldızlı otel yöneticilerine uygulanan anket sonucunda personel seçimine 
ilişkin önem verdikleri kriterlerin sıralanması yapılmıştır. Sektör yöneticilerinin görüşlerinde yabancı dil kriterinin önemi vurgulanmaktadır. Turizm sektörünün doğal yapısı gereği yabancı turistler ile iletişim kurma ihtiyacından dolayı otel yöneticileri yabancı dili iyi olan personele öncelik verileceğini ifade etmektedir. Turizmin bir ihtiyaç ve beklenti karşılama sektörü olduğu düşünüldügünde, birçok farklı karakterde insana hizmet edilmekte ve çok çeşitli ürün ve de hizmet ile turistlere karşı sorumluluğu bulunmaktadır. Bu nedenden dolayı, otel yöneticilerinin ikincil en önemli personel seçim kriterinin deneyim olarak belirttiği görülmektedir. İş tecrübesi adı da verilen deneyim unsuru, otellerde işlerin aksamaması ve daha rahat yürütülmesi için önemlidir.

Araştırma sonuçlarında işletmeye olan bağl1lık ya da diğer bir adı ile örgütsel bağl1lık unsuru, otel yöneticilerinin arzu ettiği diğer bir kriter olarak tespit edilmiştir. Personelin işletmeye sadakati ve bağl1lı̆̆1 otel yöneticilerinin personel seçiminde dikkat ettikleri diğer bir önemli unsurdur. Personelin eğitim durumu ise yukarıda belirtilen yabancı dil, deneyim ve örgütsel bağlılık unsurlarının ardından ifade edilen bir unsur olarak belirtilmiştir. Bu durum, otel yöneticilerinin turizm eğitimi ile ilgili tam olarak tatmin olmadıkları ve çok önem vermedikleri anlamına gelmektedir. Turizm ile sektör beklentileri arasında farklılık olduğu aşikardır. Personelin aldığ turizm eğitimden ise yabancı dil, iş tecrübesi ve işletmeye olan bağl1lık gibi unsurların otel yöneticileri açısından daha önemli olduğu sonucu ortaya çıkmaktadır.

Personel seçiminde bireylerin takım çalışmasına olan yatkınlığ 1 da diğer bir seçim unsurudur. Otel yöneticilerinin işletme içinde sistematik bir yapı kurmak için takım çalışmasına yatkın kişileri tercih ettikleri söylenebilir. Diğer bir kriter ise işe alınacak personelin sorumluluk sahibi olup olmadıkları durumudur. Otel yöneticileri için çok önem verilmediği ancak yine de arzu ettikleri bir kişisel özellik olduğu ifade edilebilir. Tüm kriterler arasında işe alınması istenen personelin fiziksel özelliklerinin durumu en son sırada yer almıştır. Ancak, otel yöneticilerinin bu kriter için düşünceleri diğer kriterler arasından önemsiz gibi bir sonuç gibi belirtilmiş olsa da, otellerin resepsiyon ve servis hizmetleri gibi bölümlerinde çalışan personelin fiziksel özelliklerine dikkat ettikleri bilinmektedir. $\mathrm{Bu}$ kriterlere verilen cevabın diğer kriterlere göre çok önemsiz olmadığı ve otel yöneticilerinin bu kriter için fikirlerinin diğer kriterlere göre oranladığı düşünülmektedir. Çünkü bir otelin ilk girişinde başlayan ve turistlerin ilk gördükleri kişi olan resepsiyon personelinin fiziksel olarak özenle seçildiği bilinmektedir.

Araştırma sonuçlarına göre bazı önerilerde bulunulmuştur. Giresun ili otel hizmetleri ve genel olarak personel seçimine ilişkin önerileri aşağıdaki gibi sıralayabiliriz:

Otel yöneticilerinin yabancı dil arzu ve ihtiyacı, turizm eğitimi veren eğitim kurumlarının hala yeterli yabancı dil bilgisine sahip öğrenciler yetiştiremediğini göstermektedir. Ülkemizde birçok turizm eğitimi veren kurum olmasına rağmen hala yeterli düzeyde yabancı dil seviyesine ulaşmış personel yetiştirilememektedir. Bunun için eğitim müfredatlarının, fiziksel şartların ve öğretim elemanı ihtiyacının karşılanması hem sektör hem de eğitim kurumları açısından yarar sağlayacaktır.

Elde edilen sonuçlarda iş tecrübesi unsurunun önemli olduğu ortaya çıkmıştır. Özellikle turizm eğitimi sırasında teorik derslerle birlikte uygulama ders sayısının arttırılması gerektiği sonucu ortaya çıkmaktadır. Ülkemizde birçok yüksek öğretim kurumunda staj dönemleri yaz ayları ile sınırlı kalmaktadır. Teorik dersler ve okulda geçen süre çok daha fazladır. Uygulama dersleri fazla olan ve öğrencilerini sektörde çalıştırmayı teşvik eden müfredatlar başarılı olurken, teorik dersleri fazla olan ve uygulama imkanı az olan eğitim kurumlarından sektörün beklentisini karşılayacak nitelikli personel yetiştirilmesinde zorluklar çekilmektedir. $\mathrm{Bu}$ nedenle uygulama imkanı çok daha fazla olan ve öğrencilere iş tecrübesi kazandıracak yüksek öğretim müfredatlarının oluşturulması gerekmektedir.

Eğitim konusunda otel yöneticilerinin beklentisinin düşük olması, sektör il turizm eğitimi veren kurumların arasındaki işbirliğinin az olduğunu göstermektedir. Günümüz şartlarında eğitim kurumları turizm sektörünün stajyer sorununu çözen kurumlar olarak görülmektedir. Eğitim kurumları akademisyenleri ve imkanları ile turizm sektörü ile işbirliği içinde 
çalışmalıdır. Bu durum sağlanmadıkça, eğitim kurumları ile sektörel beklentiler arasında uyum sağlanamayacaktır.

Araştırma sonuçlarında otel yöneticilerinin personel seçiminde fiziksel özellikleri göz ardı ettiği görülmektedir. Ancak, personel seçiminde özellikle turistlerle iç içe olan personelin fiziksel özelliklerine ve bakımlı olup olmadığına bakılmaktadır. Bu nedenle, otellerde çalışmayı hedefleyen bireylerin fiziksel özelliklerin ve kendilerini bakımlı olarak göstermeleri önemlidir. Araştırma sonuçları her ne kadar fiziksel özelliklerin önemini az gösterse de, sektörde fiziksel özellikler, görünüm, temizlik ve bakım önemli konular arasındadır.

Giresun ili turistik yapısı gereği ekoturizm ve kültürel turizme yatkın bir ildir. Otel yöneticilerinden elde edilen veriler doğrultusunda, arzu edilen yabancı dil konusunda diğer bölgelerden farklılık göstermektedir. İngilizce ile birlikte Arapça bilgisinin artık Giresun ili Doğu Karadeniz bölgesi için zorunlu hale geldiği görülmektedir. Bu nedenle özellikle Arapça dili konusunda eğitim kurumlarının, diğer turizm sektör kuruluşlarının eğitimlerle personel yetiştirmesi gerekmektedir.

Turizm sektörünün istihdama katkısı ve döviz sağlayıcı etkisi ekonomik anlamda ülkeler açısından önemlidir. Turizme ve turizm eğitime yapılan yatırımlarda son yıllarda artışlar çok açık şekilde görülmektedir. Ancak eğitimin niteliğinin iyileştirilmesi ve turizm yatırımlarının çevreye duyarlı ve de planlı şekilde yapılması gerekmektedir.

Turizmde çalışacak olan personelin seçimi önemli bir konudur. Özellikle il merkezlerinde faaliyet gösteren otellerin 12 ay boyunca hizmet verdiği düşünüldügünde, ülke ekonomisine önemli katkısı bulunmaktadır. Bu nedenle, otellerde çalışacak her bir personelin niteliğinin yüksek olması gerekmektedir. Otelde konaklayan veya hizmet alan bir turistin karşılaşacağı personel, turistin tekrar ziyaretinde, arkadaş ve ailesine tavsiye etmesinde ve sosyal medya ile bölgenin turizmi ile fikirlerinde bulunmasında etkili olmaktadır. İyi bir personel turistik talebin artmasına etki eden en küçük birim olarak görülebilir. Bu nedenle otel işletmelerinin yeterli seviyede yabancı dil bilgisi olan, nitelikli, personel devir hızı düşük, turiste saygılı ve eğitimli personele olan ihtiyacı sürekli olarak varolacaktır. Otel yöneticilerinin bir personelden istediği unsurların bilinmesi de sektörde iş sahibi olmak isteyen kişilerin hangi özelliklere sahip olmalarını ve belirtilen şartlara göre kendilerini eğitmeleri gerektiğini anlamalarına yardımcı olacaktır. Bu çalışma ile hem otel yöneticileri personel seçimi hakkında fikirlerini sunmuş hem eğitim kurumlarından arzu edilen personel niteliği ortaya çıkmış hem de otellerde çalışmak isteyen bireylerin hangi özelliklerin istendiği konusunda bilgiler verilmeye çalışılmıştır. Sektör temsilcilerinin personel seçimi konusunda beklenti ve isteklerinin sıralanarak sunulması hem ülke genelindeki otel yöneticilerinin bir yansıması hem de turizm eğitimi alan veya otellerde çalışmak isteyen insanlara fikir vermesi açısından önemlidir. Ayrıca, araştırma Giresun ili ile sinırlı olduğundan farklı illerde de uygulama yapılarak sonuçlar karşılaştırılabilir. Farklı şehir otellerinde yapılacak benzer çalışmalar sonucunda elde edilecek bulgular ortaya koyularak, insan kaynakları departmanının şehir otelleri içindeki durumu daha net bir şekilde analiz edilebilir. Böylelikle, hem otel işletmelerinin istihdama yönelik olarak maliyetleri azaltılabilir hem de insan kaynakları departmanın yönetilmesinde sektör yöneticilerine faydalı bir kaynak sunulabilir.

\section{KAYNAKÇA}

Başkaya, Z. ve Akar, C. (2005). Üretim alternatifi seçiminde analitik hiyerarşi süreci: Tekstil işletmesi örneği. Anadolu Üniversitesi Sosyal Bilimler Dergisi, 5(1), 273-286.

Benligiray, S. (2013). İnsan kaynakları yönetimi ve örgütlenmesi. (ed. R. Geylan ve H. Z. Tonus). İnsan Kaynakları Yönetimi. Eskişehir: Anadolu Üniversitesi Yayınları

Çetinsöz, B.C. ve Akdağ, G. (2015). Otel çalışanlarının sahip oldukları kişilik özellikleri ve iş 
performansı ilişkileri: Antalya'da faaliyet gösteren beş yıldızlı otellerde bir uygulama. Turizm Akademik Dergisi, 2(1), 1-13.

Demir, C. (2005). Konaklama işletmelerinde insan kaynakları yönetimi ilkeler ve uygulamalar. Ankara: Nobel Yayın Dağıtım.

Erdem, B. (2004). Otel işletmelerinde insan kaynakları planlamasının yeri ve önemi. Balıkesir Üniversitesi Sosyal Bilimler Enstitüsü Dergisi, 7(11), 35-54.

Genç, R. (2009).Uluslararası otel ve restoran yönetiminde insan. İstanbul: Beta Yayınları.

Giresun İl Kültür ve Turizm Müdürlüğü. (2019). Turizm işletme belgeli tesisler.

15 Haziran 2019 tarihinde http://www.giresunkulturturizm.gov.tr/TR-212249/isletme-belgelitesisler.html.adresinden erişildi.

Göral, R. (2015). E-wom'a dayalı çok kriterli karar verme teknikleri ile en uygun otelin belirlenmesi ve bir uygulama. Selçuk Üniversitesi Sosyal Bilimler Enstitüsü Dergisi, 33, 1-17.

Gümüş, M., Karabayır, A.N., Güler, T., ve Arslan, G. (2017). Alanya otel işletmelerinde Ahp metodu ile tedarikçi seçimi. Alanya Akademik Bakış Dergisi, 1(3), 1-14.

İpekçi Çetin, E., Güven, S., ve Ünal, Z. (2019). Otel işletmelerinin tedarikçi seçiminde bulanık Ahp ile ağırlıklandırılmış hedef programlama uygulaması, Hitit Üniversitesi Sosyal Bilimler Enstitüsü Dergisi, 12(1), 188-204.

İpekçi Çetin, E. ve Tarcan İçigen, E. (2018). Ahp temelli topsis yöntemi ile konaklama işletmelerinde personel seçimi, Balkan Sosyal Bilimler Dergisi, 7(13), 179-187.

Jiang, W. Y. ve Alex M. S., (1997), Human resources management: challenges for the hospitality and tourism industries. (eds. Richard Teare, Bonnie Farber Canziani and Graham Brown). London: Cassell. Global Direction.

Korucuk, S, (2018). Soğuk zincir taşımacılı̆̆1 yapan işletmelerde 3p1 firma seçimi: İstanbul örneği. Iğdır Üniversitesi Sosyal Bilimler Enstitüsü Dergisi, 16, 341-365.

Olalı, H. ve Korzay, M. (1993). Otel işletmeciliği, İstanbul: Beta Basım Yayım Dağıtım A.Ş.

Özdemir, E. ve Akpınar, A.T. (2002). Konaklama işletmelerinde insan kaynakları yönetimi

çerçevesinde Alanya'daki otel ve tatil köylerinde insan kaynakları profili. Kocaeli Üniversitesi Sosyal Bilimler Enstitüsü Dergisi, 2(3), 85-105.

Purcell J. (2003). The challenge of human resource management for industrial relations theory and practice. International Journal of Human Resource Management, 4(3), 511-527.

Saaty T.L. (1994). How to make a decision: the analytic hierarchy process. Interfaces, 24(6), 19-43.

Saaty, T.L. (2008). Decision making witht heanalytic hierarchy process. International Journal of Services Sciences, 1(1), 83-98.

Saaty, T.L. and Niemira, M.P. (2006). A framework for making a better decision. Research Review, $13(1), 1-4$.

Sadullah, Ö. (2002). Insan Kaynakları Yönetimi. Eskişehir: Anadolu Üniversitesi Yayınları.

Sarıçalı, G. ve Kundakcı, N. (2016). Ahp ve copras yöntemleri ile otel alternatiflerinin değerlendirilmesi. IREM, 4(1), 45-66.

Saruhan, Ş. ve Yıldız, M. (2012). Insan kaynakları yönetimi, teori ve uygulama. 1. Baskı. İstanbul: Beta Basım A.Ș.

Serçeoğlu, N. (2013). Konaklama işletmelerinde çalışan iş görenlerin kişilik özelliklerinin hizmet verme yatkınlığ üzerindeki etkisi. Journal of Yaşar University, 8(31), 5253-5273. 
Sonnentag, S. and Frese, M. (2002). Performance concepts and performance theory. (eds. L. Cooper \& I. T. Robertson). Psychological management of individual performance, 16-43. Chichester: John Wiley \& Sons. Ltd. DOI: 10.1002/0470013419.ch1.

Tüzün, İ.K. (2013). Konaklama işletmelerinde insan kaynakları yönetimi uygulamalarının farklılıkları ve işgücü devir hızıyla ilişkileri. İstanbul Üniversitesi İsletme Fakültesi Dergisi. 42(1), 61-76.

Ülen, M. ve Gülmez, M. (2016). Konaklama işletmelerinin tercihinde bir araç olarak Ahp yöntemi: zincir oteller üzerine bir uygulama. Verimlilik Dergisi, 1, 85-102. 